\title{
Reproductive performance of capybaras (Hydrochoerus hydrochaeris) in captivity under different management systems in Argentina
}

\author{
Martín R. ALVAREZ ${ }^{\text {a*}}$, Fernando O. KRAVETZ ${ }^{\mathrm{a}, \mathrm{b}}$ \\ ${ }^{a}$ Departamento de Ecología, Genética y Evolución, Facultad de Cs. Exactas y Naturales, Universidad de \\ Buenos Aires, Argentina \\ ${ }^{\mathrm{b}}$ in memoriam
}

(Received 18 February 2005 - Accepted 13 December 2005)

\begin{abstract}
The capybara (Hydrochoerus hydrochaeris Linnaeus, 1766) is a wild rodent of great economic interest and is easily domesticated. Variations in reproductive parameters for the capybaras depend on both intrinsic and extrinsic factors, which modulate the different stages of its reproduction either in captivity or wildlife. In captivity, an intensive production system is feasible, offering an economical profit under certain reproductive conditions. This work evaluates the reproductive performance of capybaras under different management systems in captivity, interpreting the results biologically and giving management guidelines to optimize their intensive production. The study was carried out at the Capybara Breeding Station, located in the Agricultural Experimental Station "Delta del Paraná", belonging to the National Institute for Agricultural Technology (INTA; Campana, province of Buenos Aires, Argentina; $34^{\circ} 08^{\prime} \mathrm{S}$; 58 $\left.18^{\circ} \mathrm{W}\right)$, from August 1997 to December 1998. Three different management systems were tested: System I "Isolated pens" (IP), composed of three different types of outdoor enclosures for "reproduction", "maternity" and "growth". System II "Isolated females" (IM), formed by a central enclosure ("reproduction pen"), communicating with 12 paddocks ("maternity pen") and "growth pens". System III "Mixed pens" (MP), an enclosure of $35 \times 10$-m divided in "reproduction area" and "maternity pens"; the offspring were moved to "growth pens" elsewhere. A temporary weaning technique was tested for the "mixed pens" system. The variables analyzed for all systems were litter size at birth and at weaning, nursing and interbirth periods, and survival rates (at birth, weaning and total). The reproductive efficiency of each adult female was calculated as the total number of individuals weaned alive in a one-year period. During the study, 348 young were born in 104 births, from a total of 59 adult females. We conclude that the system that performs the best for capybara reproduction is the "mixed pens" system, including temporary weaning. Under this management strategy the following parameters were registered: mean litter size of 3.8 newborn per birth; $85 \%$ of live offspring at weaning; two births per year per female; all resulting in a reproductive efficiency of 6.5 young weaned alive per year $\times$ female. These reproductive parameters provide the necessary conditions to obtain economical profit of captive-bred capybaras.
\end{abstract}

breeding management / capybara / captivity / production / reproduction

* Corresponding author: malva@uesc.br

Present address: Programa de Pós-Graduação em Zoologia, Departamento de Ciências Biológicas, Universidade Estadual de Santa Cruz (UESC), Rodovia Ilhéus / Itabuna, Km. 16 (CEP. 45662-000) Ilhéus, Bahia, Brazil. 
Résumé - Performances de reproduction du cabiaï (Hydrochoerus hydrochaeris) en captivité dans différents systèmes de production en Argentine. Le cabiaï (Hydrochoerus hydrochaeris Linnaeus, 1766) est un rongeur sauvage de grand intérêt économique qui se domestique facilement. Les paramètres de reproduction des cabiaïs varient en fonction de facteurs intrinsèques et extrinsèques qui modulent les différentes étapes de sa reproduction aussi bien en captivité qu'en milieu naturel. En captivité, un système de production intensive est viable et permet de réaliser un profit économique sous certaines conditions de reproduction. Ce travail évalue les performances de reproduction de cabiaiis élevés en captivité dans différents systèmes de production et les résultats sont interprétés d'un point de vue biologique. Des orientations pour la gestion des élevages sont proposées afin d'optimiser la production intensive de l'espèce. L'étude a été réalisée à la station d'élevage des cabiaïs, qui fait partie de l'unité expérimentale d'agriculture « Delta du Paraná » appartenant à l'INTA (Campana, province de Buenos Aires, Argentine; $34^{\circ} 08^{\prime} \mathrm{S}$; $58^{\circ} 12^{\prime} \mathrm{W}$ ), d'août 1997 à décembre 1998. Trois systèmes de gestion différents ont été testés («enclos isolés », «femelles isolées », «enclos mixtes ») ainsi qu’une technique de sevrage temporaire pour le « système des enclos mixtes ». Les variables analysées pour tous les systèmes ont été l'effectif de la portée à la naissance et lors du sevrage, les périodes d'allaitement, l'intervalle entre les naissances et les taux de survie (à la naissance, lors du sevrage et au total). Les performances de reproduction de chaque femelle adulte ont été évaluées par le nombre total d'individus sevrés vivants au cours d'une année. Pendant l'étude, 348 jeunes sont nés lors de 104 mises bas d'un total de 59 femelles adultes. Nous concluons que le système le plus performant pour la reproduction du cabiaï est le "système mixte" qui incorpore un sevrage temporaire. Avec ce système, les paramètres suivants ont été enregistrés : une portée moyenne de 3,8 nouveau-nés par mise bas ; $85 \%$ de progéniture vivante lors du sevrage; deux naissances par an et par femelle. Ceci correspond à une performance de reproduction de 6,5 jeunes sevrés vivants par année par femelle. Ces paramètres de reproduction fournissent les conditions nécessaires à l'obtention d'un profit économique de l'élevage de cabiaïs en captivité.

systèmes d'élevage / cabiaï / captivité / production / reproduction

\section{INTRODUCTION}

Wild species in South America are an exploited resource since Pre-Columbus times $[20,31,36,43]$. They have attracted scientific interest in recent years due to a growing demand of products and byproducts of animal origin, leading to an irrational hunting of many species, therefore increasing their conservation threats [39]. Because of the need of protein sources for human populations, the rational use of local fauna results in economic and social advantages and, at the same time, protecting wild populations from extinction [11, $21,24,39]$. Also, captive breeding plays a role in assessing a better knowledge of a species' biology and in reducing the ill effects of over-exploitation.

The capybara (Hydrochoerus hydrochaeris Linnaeus, 1766) is the largest living rodent in the world, with an adult weight of up to $50-\mathrm{kg}[32,37]$. It is a semi-aquatic grazing herbivore that occupies a wide array of habitats, from forested riversides to open savannas and flooded areas of South America [13, 32]. Capybaras live in social groups varying from one male and two females up to 100 individuals, with several adults of both sexes and their offspring [5, 17, 18]. Many authors have studied the species' social interactions and conclude that capybaras form cohesive groups, characterized by a complex social structure with a dominance hierarchy and individual specialization of functions $[5,14,30,37,44]$.

Capybaras are annual polyestrous animals, with spontaneous ovulation, an estrous cycle of $7.5 \pm 1.2$ days, and a receptivity period of at least 8-h [27]. Puberty in captive females is achieved between the ages of 6 to 12 months [2,23,29]. They can breed throughout the year, but do so most frequently at the onset of the rainy season; two breeding cycles are possible in an excellent habitat $[14,15,37]$. Under natural 
conditions, copulation is carried out in the water, in shallow areas [37]; in captivity copulation occurs equally frequently inside the water or on dry ground [9]. The gestation period has been estimated at approximately 150 days [9, 23, 28]. In captivity, females must be separated from the reproductive group before giving birth, because the rest of the females in the harem attack newborns [23]. However, Nogueira et al. [34] observed that aggressions only took place when pregnant females did not maintain cohesiveness with the group; otherwise, females can give birth within their reproductive group without risk of aggressiveness. Several authors describe an average litter size of 4 offspring (range 18) $[7,9,14,23,32,37,38,47]$. Newborns weigh about $1.5 \mathrm{~kg}$ and are highly precocial $[37,46]$. Juveniles suckle until 3 to 4 months of age but are able to graze within hours after their birth [5, 9, 37]. The survival rates of capybaras born in zoos are higher than those in the wild [7].

Because of its size, high reproduction potential, rapid growth, herbivore diet, the near absence of major sanitary problems, high-density grouping, easy handling, tasty meat and valuable leather, the capybara is an optimal candidate for both ranching and commercial husbandry $[13,38,39]$. Intensive production systems have been developed and tested in Venezuela [41], Colombia [12], Brazil [1, 19, 25, 35] and Argentina [3, 22]. The intensive production system is undoubtedly feasible, and becomes a profitable activity under certain reproductive conditions $[3,13]$.

Capybara reproduction depends on intrinsic and extrinsic factors. In captivity, their reproductive capacity seems to be related to density [40], the size of the enclosure [4], social status [3,9], and available quantity and quality of nutrients, such as energy, proteins [6] and ascorbic acid [10].

In this work, we evaluated the reproductive performance of capybaras under three intensive production systems, detect- ing their main handicaps and interpreting the results from a biological perspective, offering guidelines to optimize capybara management and production.

\section{MATERIALS AND METHODS}

The study was carried out at the "Módulo Experimental de Cría de Carpinchos" (Capybara Breeding Station) located in the Agricultural Experimental Station "Delta del Paraná", belonging to the National Institute for Agricultural Technology (INTA; Campana, province of Buenos Aires, Argentina; $34^{\circ} 08^{\prime} \mathrm{S}$; $58^{\circ} 12^{\prime} \mathrm{W}$ ).

The analysis was performed from $\mathrm{Au}-$ gust 1997 to December 1998. During this period the experimental females were fed with a diet composed of fresh grass, commercial food pellets and water, offered ad libitum. Since a lack of ascorbic acid in the diet produces severe deficiencies in reproduction, affecting the development of pregnancy [10], a vitamin C supplement

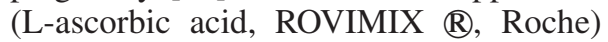
was added according to daily requirements reported for Guinea pigs [8].

All reproductive groups were a mixture of wild caught and captive born capybaras. Wild animals came from Buenos Aires and Entre Rios provinces, and had at least one year of acclimatization to captivity. Captive born animals came from the Capybara Breeding Station or from a private farm.

All facilities included a sheltered area used to protect the animals from tough environmental conditions, drinking-troughs, swimming tanks, wire troughs tightened for forage provision and food pans for commercial pellets. Three different management systems were tested (see Alvarez [3] for details of materials, constructions and logistics of all three management systems):

System I “Isolated pens" (IP). Composed of three different types of outdoor enclosures. "Reproduction pens", designed 
for courtship and mating $(9 \times 9-\mathrm{m}$, a swimming tank of $3 \times 2$ and $0.7-\mathrm{m}$ of depth, $9-\mathrm{m}^{2}$ of sheltered area), housing an adult male with a variable number ( 1 to 5 ) of females. Pregnant females were retired and isolated in a "Maternity pen" $(3.5 \times 3.0-\mathrm{m}$, without a water tank, $50 \%$ sheltered area) one month before giving birth. In these pens, parturition occurred and both the female and offspring remained until definitive weaning (4 to 6-weeks after birth). Then, the female was returned to her original harem, while the offspring were taken to "Growth pens" $(18 \times 9-\mathrm{m}$, with or without a swimming tank, two $9-\mathrm{m}^{2}$ sheltered areas).

System II "Isolated females" (IM). Occupying a $324-\mathrm{m}^{2}$ total area $(18 \times 18-\mathrm{m})$. Formed by a central enclosure of $18 \times$ 6-m (a swimming tank of $2 \times 1$ and $0.7-\mathrm{m}$ of depth, 2- $\mathrm{m}^{2}$ of covered area) where an adult male was housed, ("reproduction pen"), communicating with 12 paddocks of $3 \times 6-\mathrm{m}$ (without a swimming tank, $50 \%$ area covered) where females were individually housed ("maternity pen"). When a female entered in estrous (detected by male behavioral changes including displays and vocal communications directly in front of the female's pen) her door was opened and mating occurred in the reproduction pen. The female remained with the male while copulation was observed. After 2-weeks without copulation, the female was again confined to her individual pen. The process was repeated with each estrous female detected by the male, who were in turn occupying the central pen while copulation occurred. There were no reports of simultaneous displays from the male towards more than one potentially estrous female at a time. Each female remained in her maternity pen during gestation, birth and nursing. When offspring reached an age of 5 to 6-weeks, they were transferred to "growth pens" (variable area, with or without water tanks). The results are presented for one male and 10 females, all housed within the same general enclosure described above.

System III "Mixed pens" (MP). An enclosure of $35 \times 10-\mathrm{m}$ was primarily divided into two areas by a wired fence. Harems were located in pens composed of a "reproduction area" $(29 \times 10-\mathrm{m}$, a water tank of $2 \times 1$ and $0.7-\mathrm{m}$ of depth, $3-\mathrm{m}^{2}$ covered area), and "maternity pens", built in a second area $(2.5 \times 6.0-\mathrm{m}$ each $)$ separated from the rest of the group only by a mesh wire. Copulation occurred freely between the male and estrous females within the reproduction area. Whenever a female was in an advanced state of pregnancy, she was placed in an individual maternity pen, where births occurred, and nursing took place for 3 to 4 -weeks. After weaning, the females returned to the reproduction area and her offspring were moved to growth pens elsewhere. A total of ten harems (varying from 2 to 7 females: 1 male) were studied.

Within the "mixed pens" system (MP) a temporary weaning technique, previous to the definitive weaning, was tested. Basically, three weeks after giving birth, mothers were withdrawn from their offspring during the day and sent back to their individual maternity pen to spend the night with their litter. This lasted for three months, when definitive weaning took place and juvenile capybaras were transferred to growth pens. The results here included 41 births without temporary weaning (corresponding to 31 females) and 18 births (out of 10 females) where this practice was achieved.

The following reproductive parameters were calculated for each management system:

Mortality rate for females giving birth $=$ number of females died at birth / number of females giving birth birth

Litter size at birth $=$ total newborns per

Litter size at weaning $=$ number of offspring weaned per litter 
Nursing period $=$ days lapsed between birth and weaning

Interbirth period $/$ female $=$ days lapsed between consecutive births by the same female

Quantity of births / female $=365$ days / Interbirth period (in days)

Survival rate at birth = number of newborn alive / litter size at birth

Survival rate at weaning $=$ litter size at weaning / number of live newborn

Total survival rate = litter size at weaning / litter size at birth

Reproductive Efficiency, RE (sensu Ojasti [38]) was used as a comparative and integrative parameter to evaluate each management system and it was calculated as follows:

$\mathrm{RE}=\frac{\text { Litter size at birth } \times \text { Total Survival rate }}{\text { Quantity of females in the Reproductive pen }}$ $\times \frac{\text { Quantity of births / female }}{\text { year }}$

Each reproductive parameter and the RE were compared among management systems and for each female:male ratio for Systems I and III, using a KruskalWallis ANOVA-by-ranks test. For System III, interbirth period and survival rates were compared with or without temporary weaning, using a Mann-Whitney U test [45].

\section{RESULTS}

\subsection{Evaluation of reproductive parameters}

From August 1997 to December 1998 a total of 348 newborn out of 104 births from 59 females were registered. The average mortality rate for females giving birth was $15.52 \%$, while the others had post-partum uterus infections and remained infertile afterwards. Systems I and II recorded a similar female mortality at birth, around $20 \%$, while System III had a significant but lower value $(11.8 \%$ ) (Kruskal-Wallis ANOVA; $\mathrm{H}$ $(2,41)=8.766 ; P=0.027)$.

Overall, the three systems did not present significant differences for litter size at birth or at weaning, nursing period or interbirth period (Tab. I).

Significant differences were detected for the survival rate at birth (Kruskal-Wallis ANOVA; $\mathrm{H}(2,95)=5.688 ; P=0.047)$, with the lowest survival for System II (isolated females) $(69.8 \%)$, and no differences between Systems I and III (isolated or mixed pens) (88.5 and $85.7 \%$; respectively) (Tab. I). The "isolated females" system recorded $14.3 \%$ abortions. Survival rate at weaning showed significant differences (Kruskal-Wallis ANOVA; H (2, $73)=7.473 ; P=0.024)$ with the lowest value for System I (64.8\%) (Tab. I). The total survival rate showed significant differences among the management systems (Kruskal-Wallis ANOVA; H $(2,81)$ $=6.323 ; P=0.042$ ), the highest value corresponding to the "mixed pens" system (Tab. I).

\subsection{Effect of temporary weaning in system III}

The practice of temporary weaning in the "mixed pens" system increased the survival rate at weaning significantly, with a consequently higher total survival rate (Mann-Whitney U Test; U = 263, 264; Z-adjusted $=2.183,1.891 ; P=0.029$; 0.047 ; respectively); significant differences were not observed for the survival rate at birth (Tab. II).

Temporary weaning allowed a significant reduction of interbirth period (MannWhitney $\mathrm{U}$ Test, $\mathrm{U}=7$; Z-adjusted $=$ -4.718; $P=0.002)$. The decrease in the interbirth period with temporary weaning represents a $20 \%$ reduction in nonreproductive time among females (Tab. II). 


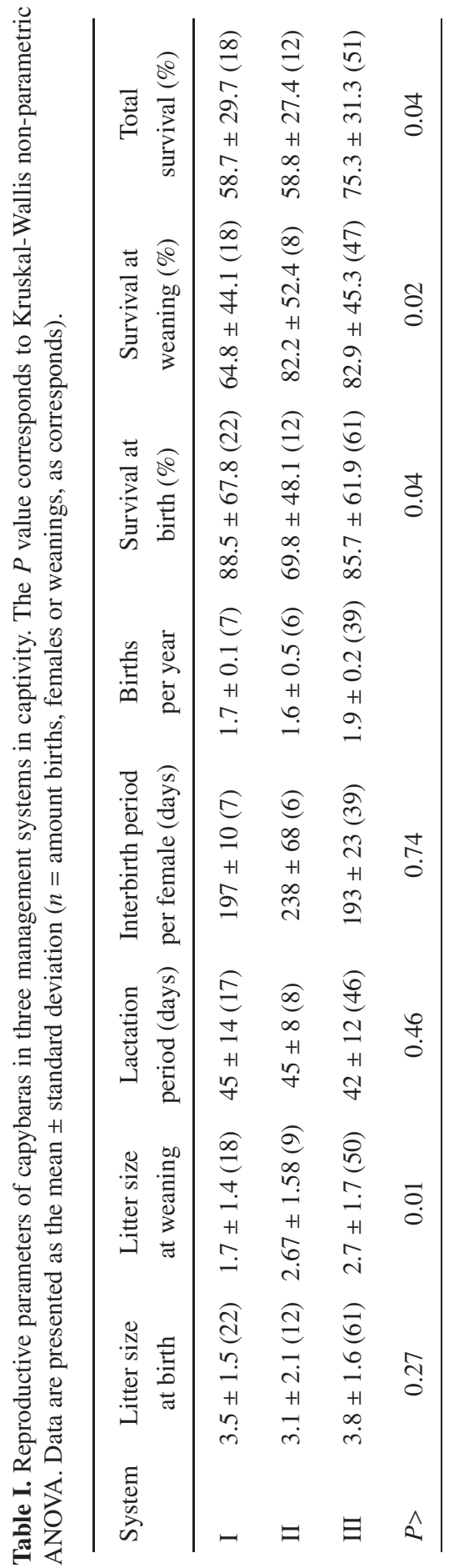


Table II. Survivorship and interbirth period with or without "temporary weaning (TW)" within System III. $P$ values corresponds to the Mann-Whitney U Test. Data are presented as mean \pm standard deviation ( $n=$ births or females, as corresponds).

\begin{tabular}{lcccc}
\hline & $\begin{array}{c}\% \text { Survival } \\
\text { at birth }\end{array}$ & $\begin{array}{c}\% \text { Survival } \\
\text { at weaning }\end{array}$ & $\begin{array}{c}\% \text { Total } \\
\text { survival }\end{array}$ & $\begin{array}{c}\text { Interbirth period } \\
\text { per female (days) }\end{array}$ \\
\hline Without TW & $15.1 \pm 25.7(41)$ & $20.3 \pm 33.6(36)$ & $32.5 \pm 36.6(40)$ & $217 \pm 36(12)$ \\
With TW & $14.4 \pm 25.3(18)$ & $2.2 \pm 6.5(18)$ & $14.4 \pm 25.3(18)$ & $180 \pm 6(7)$ \\
$P>$ & 0.91 & 0.03 & 0.04 & 0.01 \\
\hline
\end{tabular}

Table III. Reproductive Efficiency (RE) for capybaras in System I. Data are expressed as mean \pm standard deviation ( $n=$ number of enclosures).

\begin{tabular}{lcccc}
\hline Females:Males & $\begin{array}{c}\text { Litter size } \\
\text { (offspring per birth } \times \text { mother) }\end{array}$ & $\begin{array}{c}\text { Total } \\
\text { survivorship }\end{array}$ & $\begin{array}{c}\text { Births } \\
\text { per year }\end{array}$ & RE \\
\hline $1: 1$ & $3.0 \pm 1.7(7)$ & $0.5 \pm 0.2(7)$ & $1.1 \pm 0.3(7)$ & $1.6 \pm 1.3(7)$ \\
$2: 1$ & $2.3 \pm 1.1(2)$ & $0.6 \pm 0.3(2)$ & $1.3 \pm 0.1(2)$ & $2.6 \pm 2.3(2)$ \\
3 or more:1 & $3.3 \pm 1.2(3)$ & $0.6 \pm 0.1(3)$ & $1.5 \pm 0.5(3)$ & $2.4 \pm 1.5(3)$ \\
Total & $2.9 \pm 1.3(12)$ & $0.6 \pm 0.4(12)$ & $1.3 \pm 0.3(12)$ & $2.2 \pm 1.5(12)$ \\
\hline
\end{tabular}

\subsection{Reproductive efficiency (RE)}

No differences were observed in RE between captive-born capybaras (3.2 \pm 1.8; 22 females) and wild-caught animals (2.6 $\pm 2.1 ; 37$ females) (Mann-Whitney U Test; $\mathrm{U}=47.5$; Z-adjusted $=0.266 ; P=$ 0.791).

Reproductive Efficiency for System I is found in Table III, and for System III in Table IV. Since System II has only a 1:1 female:male ratio, and was developed for twelve pens, average data were as follows: litter size: $2.9 \pm 2.8$; total survival rate: $0.59 \pm 0.27$; births per year: $1.32 \pm 0.32$; and therefore RE: $2.7 \pm 2.1$ young weaning per mother and year.

The higher RE was for the "mixed pens" system (Kruskal-Wallis ANOVA; H (2, $37)=11.086 ; P=0.039)$. The average production of young weaned alive in one year was 3.3 per female.

\section{DISCUSSION}

\subsection{Evaluation of reproductive parameters}

All reproductive parameters recorded under the three management systems (Tab. I) demonstrate that capybaras reproduce successfully in captivity, with a high reproductive potential. Any reproductive female could end up producing two litters per year, totaling up to eight young. However, this is only half of the maximum registered for capybaras under captive conditions (16 young per female per year) [41].

The most critical period for female survival is while giving birth, this being the main cause of mortality of mature females in captivity [3]. Under this study, $15.5 \%$ of females died during birth, while others had post-partum uterus infections and remained infertile afterwards. Complications during birth could be associated to 
Table IV. Reproductive Efficiency (RE) for capybaras in System III. Data are expressed as mean \pm standard deviation ( $n=$ number of enclosures).

\begin{tabular}{lcccc}
\hline Females:Male & $\begin{array}{c}\text { Litter size } \\
\text { (offspring per birth } \times \text { mother) }\end{array}$ & $\begin{array}{c}\text { Total } \\
\text { survivorship }\end{array}$ & $\begin{array}{c}\text { Births } \\
\text { per year }\end{array}$ & RE \\
\hline 3 or less:1 & $3.4 \pm 0.2(2)$ & $0.7 \pm 0.1(2)$ & $1.8 \pm 0.1(2)$ & $4.7 \pm 1.4(2)$ \\
$4: 1$ & $3.3 \pm 0.3(3)$ & $0.7 \pm 0.2(3)$ & $1.8 \pm 0.4(3)$ & $3.8 \pm 1.5(3)$ \\
$5: 1$ & $3.4 \pm 0.3(3)$ & $0.7 \pm 0.1(3)$ & $1.7 \pm 0.1(3)$ & $3.5 \pm 1.3(3)$ \\
6 or more: 1 & $2.8 \pm 0.1(2)$ & $0.8 \pm 0.1(2)$ & $1.7 \pm 0.1(2)$ & $3.7 \pm 2.6(2)$ \\
Total & $3.3 \pm 1.4(10)$ & $0.7 \pm 0.1(10)$ & $1.8 \pm 0.2(10)$ & $4.3 \pm 1.7(10)$ \\
\hline
\end{tabular}

stress caused by captivity or to an excess of energy in the diet during the final stages of pregnancy [3]. Furthermore, Cueto [9] relates the occurrence of birth complications to a high investment during gestation, shown both in the number and total weight of the offspring.

No differences in litter size were observed among the three systems. However, there is a tendency in the "mixed pens" system to produce more numerous litter sizes with less variation among births (Tab. I). The litter size reported in the literature is very stable, even under different experimental conditions. The mean litter size for free-ranging populations in Venezuela is next to 4 newborn $[16,37]$. Also in Venezuela, but in captivity, average values of $4.4 \pm 1.3$ [28] and 3.7 newborn per birth [41] were reported. In Brazil, Lavorenti [25] reports an average litter size of 3.6 newborn per birth. Cueto [9] describes an average litter size of $3.4 \pm 0.2$ under the same conditions as this study. This author also showed the influence of the female nutritional condition on the mean amount of newborn per birth $(2.7$ for females in diets without ascorbic acid vs. 3.7 for diets with vitamin $\mathrm{C}$ supplementation) [9].

Nursing and interbirth periods did not vary among the three management systems (Tab. I). Cueto [9] reported that nursing has a fundamental nutritional value during the first two weeks of life, after which suckling becomes more a social behavior. Therefore, considering a mean pregnancy of 150 days and a nursing period of 30 days, the expected two births per year can be reached under this study. Lavorenti [25] reports interbirth periods of up to 283 days. Nogueira [33] points out that females in captivity had an average interbirth period of $15.7 \pm 10.4$ months, ranging from 5 to 50 months, with ovulation during lactation for $11.8 \%$ of the females.

Survival at birth is related to the management system chosen (Tab. I). Mortality in the "isolated females" system was greater than in the others; this was probably due to sanitary and social conditions of the females. Most of them were multiparous, and had social behavior conflicts after nursing in their original enclosures (exhibiting extremely aggressive or subordinate behavior). System II also included females under veterinary treatment. These variables, in addition to the capybaras being gregarious [16], might contribute to a general state of chronic stress of these females.

In a similar way, the mortality rate reported for System I prior to weaning (Tab. I) was also probably related to stress caused by handling and transport of the females. Moving from the reproduction enclosures to the maternity pens usually took place allowing for only a short period of adaptation to the new environment before 
giving birth. The "stress hypothesis" in captive capybaras might be supported by Salmon [42], who states that pregnant Mus musculus females under stress can cause infanticide of their offspring. Under nonstressful conditions, mothers can become more efficient in caring for their newborn, elevating their reproductive success.

Inexperience could also be pointed out as a potential cause for infanticide. In the capybaras, primiparous females may experience some trouble measuring the correct amount of strength needed to clean their offspring [9]. However, Nogueira et al. [34] did not find a correlation between previous experience and infanticide. In Mus тиsсulus and sheep, studies suggest that previous experience is important for maternal success $[26,42]$.

Under Systems I and II, the females were extremely isolated and therefore lost an important opportunity of learning from other mothers. While this might be beneficial to protect the newborn from other members of the group, it is important to thoroughly analyze the disadvantages of having inexperienced females that are isolated for long periods of time. These animals are unable to see other females performing the delicate task of caring for their offspring.

Under natural conditions, offspring survival is $67 \%$, and it is very difficult to distinguish between mortality at birth or during nursing [5]. Even though natural and captive conditions are by no means comparable, stressful situations can equally affect survivorship of the newborn. In this study, only the conditions in System III allowed females to perform better than in natural environments, with a total survival rate of $75 \%$. Conditions in System III can be compared with natural situations, where females close to giving birth isolate themselves to the group's periphery, while keeping visual and olfactory contact with the rest of the group [16].

\subsection{Effect of temporary weaning}

Temporary weaning resulted in a useful and easy management practice. Mothers got accustomed to this management in only 3 or 4 days, and a small paint mark allowed correct identification between mothers and offspring. Since the mother can return to the reproduction pen as early as three weeks after giving birth, temporary weaning also increased survival rates (Tab. II) and actually diminished the interbirth period.

\subsection{Reproductive efficiency}

All couples and harems of up to three females per male achieved low values of reproductive efficiency. On the contrary, larger harems had better reproductive yields (Tab. III). Unfortunately, a lack of replicates limits a more sound generalization of the optimal harem size. (Tab. IV).

Under this study's conditions, the addition of more females to a harem resulted in greater productive advantages (Tab. IV). Our results also suggest that all of the proposed systems can support groups of up to eight females per male in areas of 350 to $400-\mathrm{m}^{2}$. The single most important characteristic that must be kept in mind when designing numerous harems is density dependence. Ojasti and Sosa-Burgos [40] observed that, in captivity, capybaras show a threshold from which density affects weight gain, natality and survival of newborn and adults.

The mortality rate of newborns would be the most restrictive factor in population growth and, therefore, in the production of capybaras [5, 37, 44]. So, reproductive efficiency seems to be a less important factor, and all efforts should be focused on giving maximum care and attention to newborns. According to our results, System III allowed an optimal care of offspring (evidenced in a high survivorship at weaning) 
and achieving the highest reproductive efficiency of the three systems. Management carried out in System II was not efficient. Its only advantage was to allow the reproduction of very aggressive or subordinate females, which otherwise could not be reinstated to any reproductive group. System I showed the lowest reproductive efficiency, with the disadvantage of aggressiveness among females when returned to the reproduction pen. Agonistic behaviors associated with social organization become a considerable cost in the formation of numerous harems and reinstallation of females. This, along with the incorporation of new individuals to established groups are the major problems for capybara management. However, if individuals are added to any group as subadults, agonistic relationships are rarely present because dominance and subordination relationships appear only with sexual maturation [3].

Another advantage of System III is that, since subordinate individuals have enough space to escape from the dominant's threats, aggressions are not needed to establish social hierarchies. "Mixed pens" with "temporary weaning" adds the advantage of common identity, since maternity pens are only separated from the rest of the group by mesh wire, this results in lower newborn mortality, more births per year and, consequently, greater reproductive efficiency.

\subsection{Management implications}

Under these results, we conclude that the best management system for capybaras in a reproductive phase is System III, incorporating a temporary weaning. This management strategy results in a mean litter size of 3.8 newborn per birth; with an $85 \%$ survival rate at weaning, two births per year; and a RE of 6.5 young weaned alive per year $\times$ mother. These parameters ensure a productive benefit from raising capybaras in captivity.
González-Jiménez [13] presents guidelines in order to optimize capybara breeding in captivity and propose a litter size of 4 newborn per birth, mortality rate of $15 \%$ in offspring and interbirth periods between 180 to 200 days. As we see from this work, System III with temporary weaning, ensures these values. In addition, Alvarez [3] demonstrates that with an RE of 6 (as in System III with temporary weaning) capybara production becomes profitable with a market price around US\$ 2.50 per $\mathrm{kg}$ of meat. Even though prices vary with time and local market demands, a simple example can be given considering current prices in Brazilian and Argentinean markets, which are around 3 to 6 times superior. In Venezuela, during Lent 2005, wild capybara meat was nearly twice more expensive.

In this work we observed that there were no significant differences in the reproductive parameters between wild and captive bred capybaras, which might suggest that the origin of the animals did not influence the results. A domestication process without directed selection can be considered a type of artificial selection, where those showing a greater degree of adaptation (by surviving and successfully reproducing in captivity) pass their genes to the next generation. This research showed that during the initial phase of domestication, System III with temporary weaning was the most productive management system. Even though the experience has not been followed under the same conditions, nowadays these recommendations regarding management systems are being followed successfully by several private capybara farms in Argentina (installed in Buenos Aires, Entre Rios, Santa Fe and the Corrientes provinces). Nevertheless, we encourage further studies on reproductive management systems, constructions and materials, in order to improve capybara production in captivity. 


\section{ACKNOWLEDGEMENTS}

The animals used in this experiment were handled humanely at all times, and the capybara farm was supervised by the ethics committee of the INTA to ensure animal welfare. We thank G.R. Cueto, R. Allekotte, J. Taborda and R. Aranda for field assistance. R. Martínez and C. Miller helped with final comments and translation in English, and Y. Le Pendu with the French abstract. Marcelo Paolella from Roche

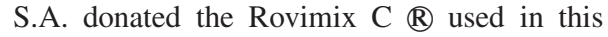
study. Special thanks are given to the anonymous reviewers who greatly contributed to the improvement of this work. This study was supported by the Consejo Nacional de Investivaciones Científicas y Tecnológicas (CONICET, Argentina) and by the Universidad de Buenos Aires (UBA, Argentina).

\section{REFERENCES}

[1] Alho C.J., Criasão e manejo de capivaras em pequenas propiedades rurãis, EMPRAPADPP, Série Documentos $\mathrm{N}^{\circ} 13$, Brasilia, Brasil, 1986.

[2] Altermann G., Leal-Zanchet A., Pubertade em fêmeas de capivaras, Hydrochoerus hydrochaeris (Mammalia, Rodentia), mantidas em sistema de criação intensiva no Río Grande do Sul, Acta Biol. Leopoldensia 24 (2002) 185-197.

[3] Alvarez M.R., Manejo sustentable del carpincho (Hydrochoerus hydrochaeris, Linnaeus 1766) en Argentina: un aporte al conocimiento de la biología de la especie desde la cría en cautiverio, Ph.D. Theses, Universidad de Buenos Aires, Buenos Aires, Argentina, 2002.

[4] Andrade P.C., Lavorenti A., Nogueira-Filho S.L., Effects of the size of area, of the diet and of the initial age of confinement on capybaras growth (Hydrochoerus hydrochaeris L. 1766), Braz. J. Anim. Sci. 27 (1998) 292299.

[5] Azcárate T., Sociobiología y manejo del capibara (Hydrochoerus hydrochaeris), Doñana Acta Vertebrata. 7 (1980) 1-228.

[6] Becker G.K., Pederassi G.C., Santos E.A., Colares E.P., Effect of food supplementation on litter size and oestradiol concentration during gestation and oestrous cycle of capybaras (Hydrochaeris hydrochaeris) in captivity, Reproduction 125 (2003) 579-583.
[7] Chapman C.A., Reproductive biology of captive capybaras, J. Mammal. 72 (1991) 206-208.

[8] Cheeke P.R., Alimentación y nutrición del conejo, Acribia, Zaragoza, Spain, 1995.

[9] Cueto G.R., Biología reproductiva y crecimiento del carpincho (Hydrochoerus hydrochaeris) en cautiverio: Una interpretación de las estrategias poblacionales, Ph.D. Theses, Universidad de Buenos Aires, Buenos Aires, Argentina, 1999.

[10] Cueto G.R., Allekotte R., Kravetz F.O., Scurvy in capybaras bred in captivity in Argentine, J. Wildlife Dis. 36 (2000) 97101.

[11] Feron E.M., New food sources, conservation of biodiversity and sustainable development: can unconventional animal species contribute to feeding the world? Biodivers. Conserv. 4 (1995) 233-240.

[12] Fuerbringer J., The capybara: a practical manual for raising them in captivity in Colombia, Temas Orientación Agropecuaria 99 (1974) 5-59.

[13] González Jiménez E., El capybara (Hydrochoerus hydrochaeris) - Estado actual de su producción, Estudio FAO Producción y Sanidad Animal $\mathrm{N}^{\circ} 122$, Roma, Italy, 1995.

[14] Herrera E.A., The effect of harvesting on the age structure and body size of a capybara population, Ecotropicos 5 (1992) 20-25.

[15] Herrera E.A., Reproductive strategies of female capybaras: dry-season gestation, in: Dunstone N., Gorman M.L. (Eds.), Behaviour and ecology of riparian mammals, Cambridge University Press, Cambridge, UK, 1999, pp. 281-296.

[16] Herrera E.A., MacDonald D., Group stability and the structure of a capybara population, Symp. Zool. Soc. Lond. 58 (1987) 115-130.

[17] Herrera E.A., MacDonald D., Resource utilization and territoriality in group-living capybaras (Hydrochoerus hydrochaeris), J. Anim. Ecol. 58 (1989) 667-679.

[18] Herrera E.A., MacDonald D., Aggression, dominance, and mating success among capybara males (Hydrochaeris hydrochaeris), Behav. Ecol. 4 (1993) 114-119.

[19] Hosken F.M., Crias̃ão e manejo de capivaras, Edişão Sebrae, Cuiabá/MT, Brazil, 1999.

[20] Humbolt A. von, Voyage aux régions équinoxiales du Nouveau Continent fait en 1799, 1800, 1801, 1802, 1803 et 1804, par Al. de Humbolt et A. Bompland. 1. Relation 
historique, N. Maze, Paris, (1819) Tome 2, pp. 1-722.

[21] Ingrand S., Hostache G., L'élevage en Guyane. Bilan des travaux réalisés sur les espèces domestiques et sur deux espèces sauvages autochtones, INRA Prod. Anim. 6 (1993) 319-332.

[22] Kravetz F.O., Allekotte R., Alvarez M.R., Cueto G.R., Un aporte a la divulgación de la cría del carpincho, Serie diversificación N 9, INTA, Buenos Aires, Argentina, 1997.

[23] Kravetz F.O., Cueto G.R., Alvarez M.R., Allekotte R., Estudios reproductivos y de estructura social del carpincho (Hydrochaeris hydrochaeris) en cautiverio, Serie diversificación $\mathrm{N}^{\circ} 10$ INTA, Buenos Aires, Argentina, 1997.

[24] Kyle R., New species for meat production, J. Agric. Sci. 123 (1994) 1-8.

[25] Lavorenti A., Domestication and potential for genetic improvement of capybara, Rev. Bras. Genet. 12 (1989) 137-144.

[26] Lévy F., Locatelli V., Piketty Y., Tillet P., Poindron P., Involvement of the main but not the accessory olfatory system in maternal behavior of primíparous and multiparous ewes, Physiol. Behav. 57 (1995) 97-104.

[27] López-Barbella S., Determinación del ciclo estral en chigüires (Hydrochoerus hydrochaeris), Acta Cient. Venez. 33 (1982) 497-501.

[28] López-Barbella S., Consideraciones generales sobre la gestacion del chigüire (Hydrochoerus hydrochaeris), Acta Cient. Venez. 38 (1987) 84-89.

[29] López-Barbella S., Pubertad en hembras chiguires (Hydrochoerus hydrochoeris), Rev. Fac. Agron. (Maracay) - UCV 19 (1993) 121-127.

[30] MacDonald D., Dwindling resources and the social behaviour of capybaras, (Hydrochoerus hydrochaeris) (Mammalia), J. Zool. (Lond.) 194 (1981) 371-391.

[31] Mondolfi E., El Chigüire, Volume 168, El Farol. Caracas, Venezuela, 1957.

[32] Mones A., Ojasti J., Hydrochoerus hydrochaeris, Mammalian Species 264 (1986) $1-7$.

[33] Nogueira S.S., Manejo reproductivo da capivara (Hydrochoerus hydrochaeris hydrochaeris L. 1766) sob sistema intensivo de criação, Ph.D. Theses, Universidade de São Paulo, São Paulo, Brazil, 1997.
[34] Nogueira S.S., Nogueira-Filho S.L., Otta E., Dias C.T., Carvalho A., Determination of infanticide causes in capybara (Hydrochaeris hydrochaeris) groups in captivity, Appl. Anim. Behav. Sci. 62 (1999) 351-357.

[35] Nogueira-Filho S.L., Manual de criação da capivara, Viçosa - MG, Centro de Produçoes Técnicas - CPT, Brazil, 1996.

[36] Nogueira-Neto P., A criação de animais indígenas vertebrados. Peixes, anfíbios, repteis, aves, mamíferos, Editora Tecnapis, São Paulo, Brazil, 1973.

[37] Ojasti J., Estudio biológico del chigüire o capibara, Fondo Nacional de Investigaciones Agropecuarias, Caracas, Venezuela, 1973.

[38] Ojasti J., Human exploitation of capybara, in: Robinson J.G., Redford K.H. (Eds.), Neotropical wildlife use and conservation, The University of Chicago Press, Chicago, USA, 1991, pp. 236-252.

[39] Ojasti J., Utilización de la fauna silvestre en América Latina. Situación y perspectivas para un manejo sostenible, Guía FAO Conservación $\mathrm{N}^{\circ} 25$, Roma, Italy, 1993.

[40] Ojasti J., Sosa Burgos L.M., Density regulation in populations of capybara, Acta Zool. Fenn. 173 (1985) 81-83.

[41] Parra R., Escobar A., González Jiménez E., El chigüire: su potencial biológico y su cría en confinamiento, Informe Anual del Instituto de Producción Animal, Universidad Central de Venezuela, Maracay, Venezuela, 1978.

[42] Salmon C.C., Differences in patterns of pup care in Mus musculus domesticus. VIII Effects of Previous Experience and Parity in XLII Inbred Mice, Physiol. Behav. 40 (1987) 177-180.

[43] Santoja M., Los hombres de la yuca y el maíz, Editorial Monte Avila, Caracas, Venezuela, 1981.

[44] Schaller G.B., Crawshaw P.G., Social organization of a capybara population, Saugetierk. Mitt. 29 (1981) 3-16.

[45] Siegel S., Castellan N.J., Estadística no paramétrica aplicada a las ciencias de la conducta, Editorial Trillas, Mexico D.F., Mexico, 1998.

[46] Weir B.J., Reproductive characteristics of hystricomorph rodents, Symp. Zool. Soc. Lond. 34 (1974) 265-301.

[47] Zara J.L., Breeding and husbandry of the capybara, Hydrochaeris hydrochaeris, at Evansville Zoo, Int. Zool. Yearbook 13 (1973) 137-139. 